\title{
Personal Protective Equipment used in Coronavirus
}

\section{Pandemic}

\begin{abstract}
Ali ASAN iD
Department of Iinfectious Disease, University of Health Sciences, Bursa Yüksek İhtisas Training \& Resarch Hospital, Bursa, Turkey
\end{abstract}

Turk J Int Med 2020;2(2): 33-34

DOI: $\underline{10.46310 / \text { tjim.726489 }}$

Cases of pneumonia of unknown etiology in Wuhan, China's Hubei province, was reported to the China country Office of the World Health Organization (WHO) on December 31, 2019. The causative agent was identified as a new coronavirus (2019-nCoV) on January 7, 2020 that has not previously been detected in humans. Later, the name of 2019-nCoV disease was accepted as COVID-19, and the virus was named as SARS-CoV-2 due to its similarity to SARS CoV. ${ }^{1-3}$

During the SARS-CoV-2 pandemic period, special attention should be paid to personal protective equipment (PPE). Medical staff protection is particularly important because of the risk of infecting other medical team members, not only doctors, nurses or paramedics, but also other support staff necessary to ensure continuity of care for patients. ${ }^{4,5}$

It is important for the healthcare professionals working in triage to wear a medical mask and provide at least 1-meter distance to the patients and give a medical mask to the patients who apply to triage without wearing a mask. Laboratory workers are required to wear medical masks, gowns, gloves while working with breathing samples and glasses / face shields during operations with the risk of splashing.

Health personnel working in the outpatient clinic should use PPE according to standard measures and risk assessment. During the examination of the patient with respiratory symptoms, a medical mask, gowns, gloves, glasses / face shields should be used, and during the examination of patients without respiratory symptoms, the patient should wear a medical mask.

In emergency departments, it is recommended to use N95 or FFP2 or equivalent masks, gloves, glasses / face shields and gowns during the examination of patients referred to COVID emergency clinics in reserved area for the examination of possible coronavirus cases. Also, healthcare professionals working in sampling units designated in these areas should consider all samples taken as potentially infectious, sampling should be considered as the process that causes aerosolization, and individuals should have personal protective equipment (at least N95 / FFP2 mask, glasses or face protection). ${ }^{6}$

It is recommended that the healthcare personnel entering the patient room should use medical masks, gowns, gloves, glasses / face shields, and use N95, FFP2 or equivalent mask during aerosol-forming procedures. When entering the patient room, cleaning staff are recommended to wear medical masks, gowns, gloves, glasses and to use face shield if there is a risk of organic or chemical material splash.

Under normal conditions, visitors are not allowed in the patient room. If it is necessary to enter the COVID-19 patient room, they should be informed and supervised by a healthcare professional about wearing a medical mask, gowns, and gloves, before and after wearing PPE. ${ }^{6}$

Despite many innovations in infection control

Received:April 24,2020;Accepted:April 26,2020; Published Online:April 29,2020
Address for Correspondence:
AliASAN
Department of Iinfectious Disease, University of Health Sciences,
Bursa Yüksek İhtisas Training \& Resarch Hospital, Bursa, Turkey
E-mail:draasan@yahoo.com


and prevention in hospitals, tuberculosis, multidrugresistant bacteria, SARS CoV in 2003, MERS CoV in 2012 and COVID-19 pandemics that emerged this year have once again have shown us that hand hygiene and isolation precautions are very important. The main purpose in isolation is to prevent the transmission of microorganisms from infected or colonized patients to other patients, patient visitors and health personnel. ${ }^{7}$

Isolation can be grouped under two headings as standard precautions and precautions for transmission. Standard precautions are measures applied to all patients regardless of the patient's diagnosis and whether they have an infection. In the care of all patients, they are the first precautions to be applied against blood, body fluids and extracts. The basis of these is the cleaning and the use of appropriate barriers that will prevent the contact with the risky material. Before contact with contaminated material (blood, body fluids, secretions other than sweat and all extracts, impaired skin and mucous membranes, contaminated items ...); gloves, masks and protective gowns are worn and if it is necessary, eye protection (glasses or face shield) should be made in case of droplet formation risk. Gloves must be removed, and hands washed before touching clean items or another patient. ${ }^{8}$

Contact and droplet isolation is important in COVID patients in the prevention for transmission. Contact precautions should be applied in addition to standard precautions to prevent direct or indirect contact (contact with infected objects) from patients infected or colonized samples. ${ }^{7,8}$

It should be applied in addition to standard measures to prevent the passage of large particle ( $>$ $5 \mu \mathrm{m})$ droplets. There should be more than 1-meter distance between the source and the sensitive person to avoid contamination. Speaking, coughing or nasal wiping, aspiration, intubation, bronchoscopy of infected patients may infect the susceptible person through the nose, mouth and conjunctiva. When a condition requiring droplet isolation is detected or suspected, the patient should be placed in a single room. Access to the patient room should be restricted, only personnel responsible for the patient's care and required access should be allowed to enter the room, patient visitors should be banned, and the companion should be restricted to one person if necessary. At the entrance of the patient room; personal protective materials (gloves, gowns (non-sterile, preferably liquid impermeable and long sleeve), medical mask, at least N95 / FFP2 mask, glasses / face shields, alcohol-based hand antiseptics and alcohol-based rapid surface disinfectant) should be ready. People who make examination, treatment and personal care should wear gloves, isolation gowns, glasses / face shields, and medical masks. Care should be taken to use gloves, isolation gowns, N95 / FFP2 mask and face shields when attempting to cause aerosolization of the patient's secretions and the body fluids..$^{6-8}$

\section{Conflict of interest}

The author declared that there is no potential conflict of interest with respect to the research, authorship, and/or publication of this article.

\section{References}

1. https://www.who.int/emergencies/diseases/novelcoronavirus-2019/events-as-theyhappen. [cited $2020 \mathrm{Apr}$.

2. Andersen KG, Rambaut A, Lipkin WI, Holmes EC, Garry RF. The proximal origin of SARS-CoV-2. Nat Med. 2020 Apr;26(4):450-452. doi: 10.1038/s41591-020-0820-9.

3. T.C. Sağlık Bakanlığı Halk Sağlığ Genel Müdürlüğü, COVID-19 (SARS-CoV-2 Enfeksiyonu) Rehberi, Bilim Kurulu Çalışması. Ankara: T.C. Sağlık Bakanlığı; 14.04.2020: 1-95. Available from: https:/covid19bilgi. saglik.gov.tr/depo/rehberler/COVID-19_Rehberi.pdf. [cited 2020 Apr].

4. Wax RS, Christian MD. Practical recommendations for critical care and anesthesiology teams caring for novel coronavirus (2019-nCoV) patients. Can J Anaesth. 2020 May;67(5):568-576. doi: 10.1007/s12630-020-01591-x.

5. Smereka J, Szarpak L. COVID 19 a challenge for emergency medicine and every health care professional. Am J Emerg Med. 2020 Mar 24. pii: S0735-6757(20)301807. doi: 10.1016/j.ajem.2020.03.038.

6. T.C. Sağlık Bakanlığı. COVID-19 Hastalığına Yönelik Sağlık Kuruluşu, Personel Ve Faaliyet Türüne Göre Kullanılması Önerilen Koruyucu Ekipmanlar. T.C Sağlık Bakanlığı Halk Sağlığı Başkanlığı Dökümanı. Ankara: https://covid19bilgi.saglik.gov.tr/depo/enfeksiyonkontorl-onlemleri/KISISEL_KORUYUCU_EKIPMAN_ KULLANIMI.pdf. [cited 2020 Apr].

7. Siegel JD, Rhinehart E, Jackson M, Chiarello L, and the Healthcare Infection Control Practices Advisory Committee. 2007 Guideline for Isolation Precautions: Preventing Transmission of Infectious Agents in Healthcare Settings. Last update: July 2019: 1-206. Available from: https://www.cdc.gov/infectioncontrol/pdf/ guidelines/isolation-guidelines-H.pdf. [cited 2020 Apr].

8. World Health Organization Scientific brief. Modes of transmission of virus causing COVID-19: implications for IPC precaution recommendations. 29.03.2020. Available from: https://www.who.int/news-room/commentaries/ detail/modes-of-transmission-of-virus-causing-covid-19implications-for-ipc-precaution-recommendations. [cited $2020 \mathrm{Apr}]$. 